\title{
Conceptual Design of Moored Floating Meterological Buoy with LiDAR
}

\author{
Jeongrok Kim*, Hyebin Lee* , Il-Hyoung Cho*, Nam-Ho Kyong ${ }^{* * *}$ and Sung-Youn Boo ${ }^{* * * *}$ \\ "Department of Ocean System Engineering, Jeju National University, Jeju, Korea \\ ${ }^{* *}$ Multidisciplinary graduate school program for wind energy, Jeju National University, Jeju, Korea \\ ${ }^{* * *}$ Korea Institute of Energy Research, Wind Energy Research Center, Jeju, Korea \\ ${ }^{*}$ VL Offshore Limited Liability Company, Texas, Houston, USA
}

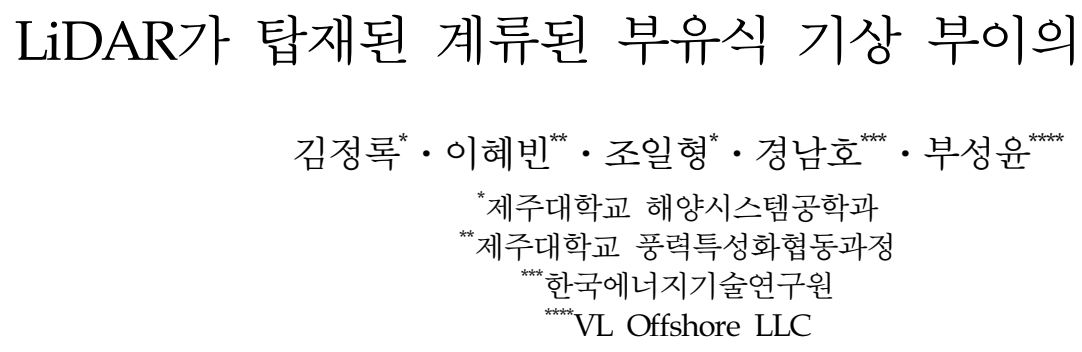

KEY WORDS: Motion response 운동 응답, Model test 모형 실험, Design process 설계 과정, Offshore wind energy 해상 풍력, Meterological buoy 기상 부이

\begin{abstract}
This paper reports the conceptual design process for a floating metocean data measurement system (FMDMS) for measuring wind information at sea. The FMDMS consists of three circular pontoons, columns, and a deck, which the LiDAR (lighting detection and ranging) is installed on. The dynamics of the mooring lines and motion responses of the FMDMS were analyzed using commercial codes such as WAMIT and OrcaFlex. One design criterion of the developed FMDMS was to maintain the motion responses as small as possible to enhance the LiDAR's accuracy. Starting with the preliminary design parameters such as the FMDMS's principal dimensions, weight, and important parameters of mooring system, we checked whether the FMDMS met the design requirements at each design stage, and then made modifications as necessary. The developed FMDMS showed a large pitch behavior for a small heave motion.
\end{abstract}

\section{1. 서 론}

바람이 지닌 에너지를 이용하여 전기 에너지를 생산하는 풍 력발전은 최근 수십 년간 활발한 연구가 진행돼 왔고, 그 결과 로 풍력발전산업은 관련 기술의 축적 및 고도 성장을 이루었다. 이와 함께 바람 데이터를 수집하기 위한 측정 기술 분야도 동 반 성장하였다. 최근에는 해상풍력에 관한 관심이 높아지면서 해상의 바람자료를 취득하기 위한 방안으로 고정식 기상탑을 활용하고 있다. 그러나 고정식 기상탑을 심해에 설치하기에는 제작/설치에 따른 비용 부담이 너무 커서 그 대안으로 부유식 기상 부이 개발이 필요하게 되었다. 풍력 발전기의 발전량 예측 및 경제성 평가를 위해서는 터빈이 위치한 높은 지점에서의 바 람 데이터가 필요하다. 높은 고도에서의 바람 데이터를 취득하 기 위해 기상탑을 높게 세우는 대신에 소형 LiDAR(Light and detection and ranging) 장비를 활용한다(Jaynes et al., 2007). LiDAR 장비는 레이저를 이용하여 고도 $300 \mathrm{~m}$ 까지 바람 정보를 계측할 수 있으며, 소형이기 때문에 부이에 탑재가 가능하므로 전체 시스템의 제작비용을 크게 줄일 수 있는 장점을 가지고 있다.

기상 부이와 같은 해상 부유식 구조물의 설계는 Fig. 1 과 같 이 여러 단계의 설계 절차를 거쳐 진행된다. 부유식 해상 구조 물은 운용 목적과 설치해역의 환경조건에 따라 전체 크기와 주 요 제원들을 결정한다. 그리고 정적 해석(Static analysis)을 통하 여 구조물의 안정성을 평가하고 정유체 복원력 계수를 구한다. 다음 단계로 파랑중 동적 해석을 주파수영역 해석과 시간영역 해석으로 구분하여 실시한다. 이를 위하여 WAMIT, OrcaFlex와 같은 상용코드를 이용하여 동유체력과 파기진력을 구하고 필요 에 따라 조류하중(Current force)과 풍하중(Wind force)을 포함시

Received 27 April 2017, revised 12 September 2017, accepted 19 October 2017

Corresponding author Il-Hyoung Cho: +82-10-9232-1253, cho0904@jejunu.ac.kr

(c) 2017, The Korean Society of Ocean Engineers

This is an open access article distributed under the terms of the creative commons attribution non-commercial license (http://creativecommons.org/licenses/by-nc/3.0) which permits unrestricted non-commercial use, distribution, and reproduction in any medium, provided the original work is properly cited. 


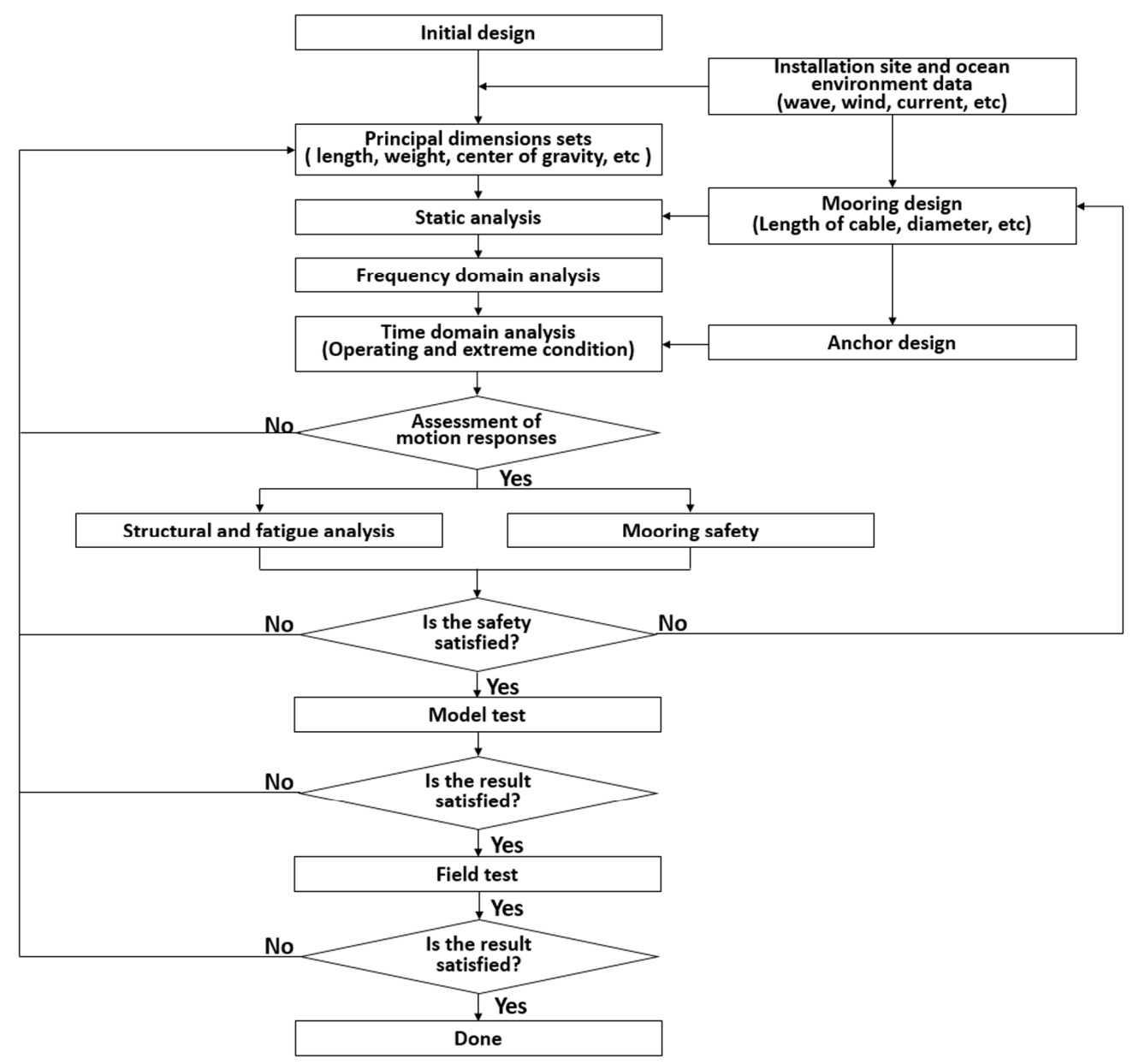

Fig. 1 Design procedure of a floating offshore structure

킨다. 운동방정식을 풀어 부유식 구조물의 6자유도 운동응답을 구한다. 이때 환경외력조건을 운용 조건(Operating condition)과 극한 조건(Extreme condition)으로 나눠 운동 해석을 실시한다. 특히, 극한 조건에서는 부유식 구조물의 운용 기간과 관련 있는 특정 재현주기(Return period)에 해당되는 설계환경에서 최대 하 중을 구하고 구조물의 안전성과 계류시스템의 파손 여부를 판 단한다. 이 단계에서 구조물의 안전성이 확보되고 계류 시스템 에 큰 문제가 발생하지 않는다고 판단되면 축소모형을 제작하 여 모형실험을 실시한다. 모형실험을 통하여 얻은 실험결과와 수치해석 결과를 서로 비교함으로써 수치모델에서 간과된 비선 형 효과와 점성의 영향을 고려할 수 있다. 끝으로 축척비로 인 한 모형실험 결과의 오차를 보정하기 위하여 실해역 실증 실험 을 수행한다. 본 논문은 Fig. 1에 제시한 설계 절차에 따라 부유 식 해상 기상 부이에 대한 개념 설계와 모형실험까지의 설계 과정을 다루었으며, 구조 및 피로해석은 제외하였다.

해상에서 높은 고도의 풍속을 측정하기 위하여 부이에 $\mathrm{LiDAR}$ 를 설치하여 운용하는 방법은 최근 들어 많은 연구가 수 행되었다. Mathisen(2013)은 LiDAR를 육상과 원반형(Disk type) 부이에 설치하여 각 지점에서 측정된 바람 데이터의 비교 - 분 석하는 연구를 실시하였으며, Jaynes and Hassan(2011)은 선박형 (Ship type) 소형 부이에 LiDAR를 탑재하여 실해역 실증 실험을 수행하였고, 오차범위 $2 \%$ 이내의 풍속 데이터를 얻었다. 한편,
국내의 기상 부이에 관한 연구는 다수 존재하지만, LiDAR가 탑 재된 기상 부이에 대한 연구는 미미하다. Cho and Yi(1997)가 해양 관측용 부이의 개념설계를 수행하였고, 설치 해역의 환경 외력조건을 고려하여 부이의 작용하는 하중을 구하고 계류시스 템을 설계하였다. Lee et al.(1999)이 수중 소음을 측정하여 그 결과로부터 해상풍의 정보를 얻는 연구를 수행하여 수중 소음 과 지상 기상관측소에서 측정된 풍속과의 상관 관계식을 유도 하였다. 측정결과, 풍속의 오차범위는 $1 \mathrm{~m} / \mathrm{s}$ 수준으로 만족할만 한 성과를 얻었다. Moon et al.(2013) 등은 해상 풍력발전단지 설계를 위해 우리나라 신안군 우이도 인근 수심 약 $10 \mathrm{~m}$ 해역에 높이 $120 \mathrm{~m}$ 의 'Ocean MAST'기상 타워를 세웠고, 측정된 풍황 자료는 한반도 바람지도 작성에 활용되고 있다. 이와 같이 해상 의 바람을 측정하기 위해 다양한 방법들이 제시되고 있으며, 이 를 기반으로 해상 풍력 개발을 위한 다양한 연구들이 수행되고 있다(Kim, 2003; Lee and Shin, 2012).

본 연구에서는 LiDAR가 탑재된 기상 부이 개발을 목표로 설 계를 진행하였으며, 논문의 구성은 다음과 같다. 먼저 2장에서 는 설계된 기상 부이의 특징과 제원, 해양환경조건을 소개하였 다. 기상 부이는 3 개의 폰툰으로 구성된 반잠수식 구조물로써 기존의 원반형 또는 스파형(Spar type) 구조물과는 하부 구조물 형상에 큰 차이가 있다. 3장에서는 WAMIT과 OrcaFlex 상용코 드를 이용하여 주파수영역 해석과 계류시스템을 포함한 시간영 
역 해석을 다루었다. 이때 1년 재현 주기를 갖는 파랑 조건을 설계파로 잡아 계류시스템의 안전성을 평가하였다. 그리고 4장 에서는 계류시스템을 포함한 축척비 $1 / 10$ 실험 모형을 제작하여 사각형 조파수조에서 파랑중 규칙파, 불규칙파 운동 실험을 수 행하였다. 끝으로 5 장에서 중요한 결론들을 도출하였다.

\section{2. 기상 부이와 파랑 조건}

\section{1 기상 부이}

국내 해양환경조건에 적합한 부유식 기상 부이(Floating metocean data measurement system, FMDMS)를 개발하기 위한 개념 설계 된 기상 부이 모델은 Fig. 2에 제시하였다. FMDMS의 주요 구성 요소를 살펴보면 부력을 주는 3 개의 플라스틱 폰툰(Pontoon)이 정삼각형 모양으로 배열되어 있고, 중심부에 위치한 주 기둥 (Main column)과 폰툰 하단부에 위치한 외부 기둥(Outer column) 이 다수의 브레이스(Brace)로 연결되어 구조적 안정성을 갖도록 하였다. 폰툰 위에 놓인 데크(Deck)에는 타워(Tower)와 LiDAR

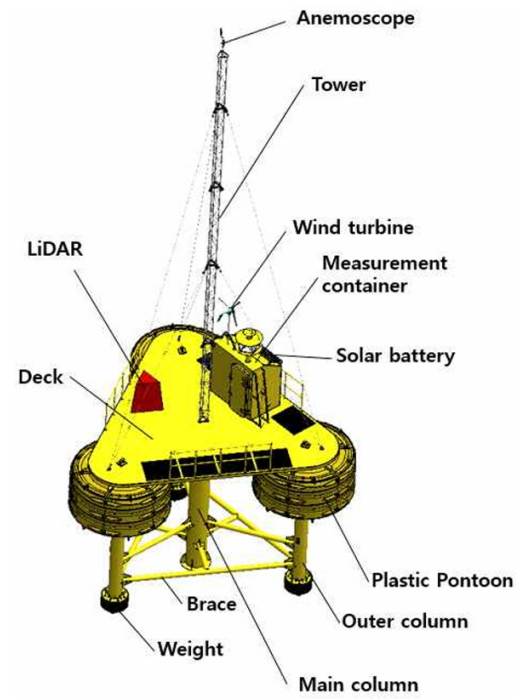

Fig. 2 Conceptual design of a FMDMS
Table 1 Specifications of the FMDMS

\begin{tabular}{lcc}
\hline \hline \multicolumn{1}{c}{ Item } & Unit & Value \\
\hline Mass & {$[\mathrm{kg}]$} & 15,705 \\
Draft of main column & {$[\mathrm{m}]$} & 4.375 \\
Column spacing & {$[\mathrm{m}]$} & 5.5 \\
Diameter of main column & {$[\mathrm{m}]$} & 0.609 \\
Diameter of pontoon & {$[\mathrm{m}]$} & 3.0 \\
Moment of inertia (about center of gravity) & {$\left[\mathrm{kg} \cdot \mathrm{m}^{2}\right]$} & $161,150.74$ \\
Center of gravity from SWL $\left(z_{G}\right)$ & {$[\mathrm{m}]$} & -0.9928 \\
Metacentric height GM & {$[\mathrm{m}]$} & 6.35 \\
Heave natural period & {$[\mathrm{s}]$} & 2.73 \\
Pitch natural period & {$[\mathrm{s}]$} & 3.07 \\
\hline
\end{tabular}

계측장비 그리고 계측장비 운용에 필요한 배터리와 데이터 송 수신 장치가 탑재된 컨테이너 박스가 있다. FMDMS의 질량은 $15,705 \mathrm{~kg}$, 주 기둥의 흘수는 $4.375 \mathrm{~m}$ 이다. 폰툰의 직경은 $3 \mathrm{~m}$, 기 둥간 거리는 $5.5 \mathrm{~m}$ 로 설계되었으며, $\mathrm{GM}$ 값은 $6.35 \mathrm{~m}$ 로 복원 안정 성은 확보되었다. 일반적으로 부유체는 공진 시 운동이 급격히 커질 수 있기 때문에 공진 회피 설계가 필요하다. FMDMS의 수 직, 종 운동 고유주기는 각각 $2.73 \mathrm{~s}, 3.07 \mathrm{~s}$ 로 설치 해역의 파주기 분포를 살펴볼 때 단주기 영역에 위치한다. FMDMS의 제원은 Table 1에 자세히 수록하였다.

\section{2 해양환경 조건}

본 논문에서 제안된 기상 부이는 제주도 동쪽 월정리 부근 수 심 $30 \mathrm{~m}$ 해역에서 실증 실험을 계획하고 있다. Fig. 3는 ECMWF (European Center for Medium range Weather Forecasts)의 19792003 년의 25년간의 자료를 이용하여 산출된 월정리 해역의 파 랑 정보를 보여주고 있다. 주 파향은 $315^{\circ}$ 이며, 평균 피크 주기 의 대역은 약 $6-7.7 \mathrm{~s}$, 평균 유의 파고의 최댓값은 파향 $315^{\circ}$ 에서 $1.67 \mathrm{~m}$ 로 나타나고 있다.

계류시스템은 FMDMS의 위치 유지를 위해 필요한 장치로 설 계파(Design wave) 조건에서 계류선이 파단 되지 않도록 설계되

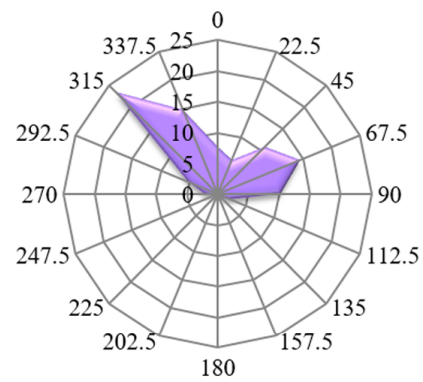

$<$ wave direction $>$

$315.0^{\circ}: 23.3 \%$

$337.5^{\circ}: 14.7 \%$

$67.5^{\circ}: 14.4 \%$

$45.0^{\circ}: 10.8 \%$

$90.0^{\circ}: 10.0 \%$

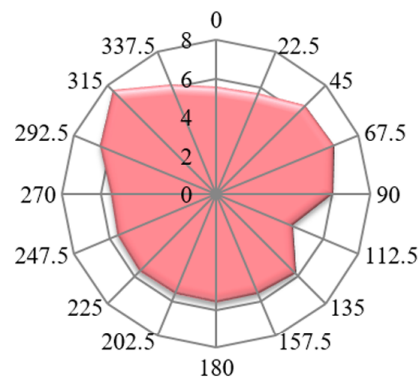

$<T_{p_{-} \text {mean }}>$

$315.0^{\circ}: 7.63 \mathrm{sec}$

$337.5^{\circ}: 6.13 \mathrm{sec}$

$67.5^{\circ}: 6.58 \mathrm{sec}$

$45.0^{\circ}: 6.47 \mathrm{sec}$

$90.0^{\circ}: 6.03 \mathrm{sec}$

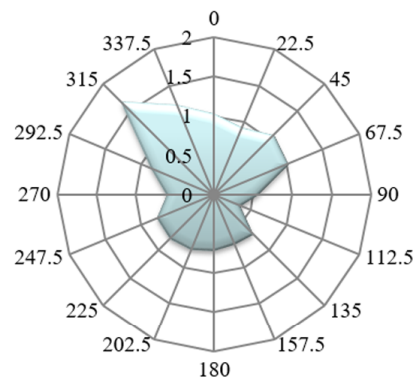

$<H_{S_{-} \text {mean }}>$

$315.0^{\circ}: 1.67 \mathrm{~m}$

$337.5^{\circ}: 1.24 \mathrm{~m}$

$67.5^{\circ}: 1.02 \mathrm{~m}$

$45.0^{\circ}: 1.07 \mathrm{~m}$

$90.0^{\circ}: 0.55 \mathrm{~m}$

Fig. 3 Wave conditions at Waljeong sea 
Table 2 Design wave conditions for mooring system

\begin{tabular}{ccccccc}
\hline \hline \multirow{2}{*}{ Condition } & \multicolumn{3}{c}{ Wave (JONSWAP spectrum) } & & \multirow{2}{*}{$\begin{array}{c}\text { Current speed } \\
\text { at surface }[\mathrm{m} / \mathrm{s}]\end{array}$} & $\begin{array}{c}\text { Wind speed } \\
(10 \mathrm{~m} \text { above SWL) [m/s] }\end{array}$ \\
\cline { 2 - 4 } & $\mathrm{H}_{\mathrm{S}}[\mathrm{m}]$ & $\mathrm{T}_{\mathrm{P}}[\mathrm{s}]$ & $\gamma$ & & 1.140 & 18.36 \\
\hline Extreme (1 year return period) & 5.74 & 10.81 & 2.2 & & 140 \\
\hline
\end{tabular}

어야 한다. 또한 앵커는 조류나 파랑 등에 의해 이동되지 않도 록 적정 중량을 확보하는 것이 중요하다. 설계파 산정은 부유체 의 수명을 좌우하기 때문에 일반적으로 설계파 조건을 50년 또 는 100 년 재현 주기를 갖는 극한 조건으로 선정한다. 그러나 실 증 실험을 목표로 한 현 설계/제작을 고려할 때 1 년 재현 주기 에 해당하는 외력조건을 적용하였다. 1 년 재현주기에 해당하는 파랑, 조류, 바람에 대한 대폿값으로 제주도 서쪽 차귀도 해역 에서 오랜 기간 측정한 데이터를 통해 얻은 값을 사용하였다 (Kim et al, 2015) (Table 2 참조).

\section{3. 수치 해석}

\section{1 주파수영역 해석}

파랑중 부유체의 운동응답을 구하기 위해서는 식 (1)의 나타낸 6 자유도 운동 방정식을 풀어야 한다. 여기서 $m_{i j}, a_{i j}$ 는 관성항과 부가질량항이며, $b_{i j}$ 는 방사 감쇠계수 그리고 $k_{i j}^{(S)}, k_{i j}^{(M)}$ 는 각각 정 유체력 계수와 계류라인의 복원력 계수를 나타낸다. $A, E_{i}$ 는 입사 파의 진폭과 단위 진폭당 파기진력을 나타낸다. $i, j=1,2,3$ 은 병 진운동 모드, 그리고 $i, j=4,5,6$ 은 회전운동 모드를 나타낸다. 부 가 질량, 방사 감쇠계수 그리고 파기진력은 WAMIT 상용코드를 이용하여 구하였다. WAMIT은 Green 함수법에 기초를 둔 수치해 석 방법으로 이를 적용하기 위하여 FMDMS의 수면아래 형상을 Fig. 4 와 같이 17,000 개의 요소(Panel)로 분할하였다. LiDAR의 측 정 오차를 발생시키는 주요 원인은 부유체의 종 운동(Pitch motion)이다. 따라서 6자유도 운동중에서 주로 종 운동에 초점을 맞추어 결과를 살펴보았다. Fig. 5는 WAMIT 수치해석 결과로써 FMDMS의 종 운동에 관한 RAO(Response amplitude operator), 종 방향 파기진모멘트 $\left(E_{5}\right)$, 부가 관성모멘트 $\left(a_{55}\right)$, 방사 감쇠계수 $\left(b_{55}\right)$ 이다.

종 운동의 비감쇠 고유주파수(Undamped natural frequency) $\omega_{n}$ 는 식 (2)와 같이 구할 수 있다. 종 운동 고유주파수는 입사파 주파수와 일치될 때 공진으로 종 운동이 크게 발생하며 이는 종운동 $\mathrm{RAO}\left(=\left|\xi_{5} /(k A)\right|\right)$ 곡선에서 뚜렷하게 확인할 수 있다. 부가 관성모멘트는 고주파수 영역으로 접근함에 따라 일정한 값으로 수렴하고 있으며, 방사 감쇠계수와 파기진력은 저주파
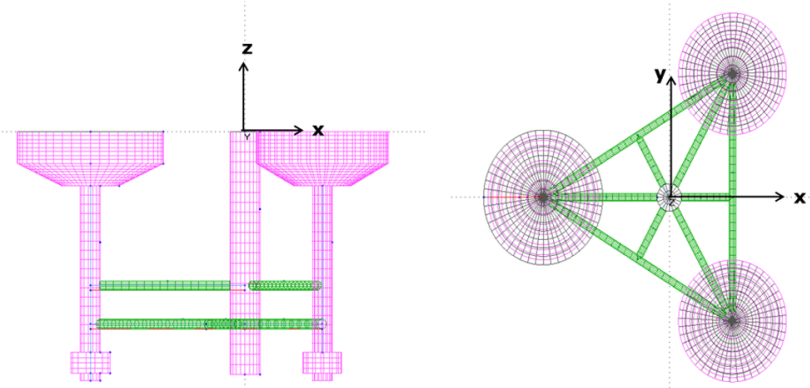

Fig. 4 Numerical model of FMDMS for WAMIT commercial code
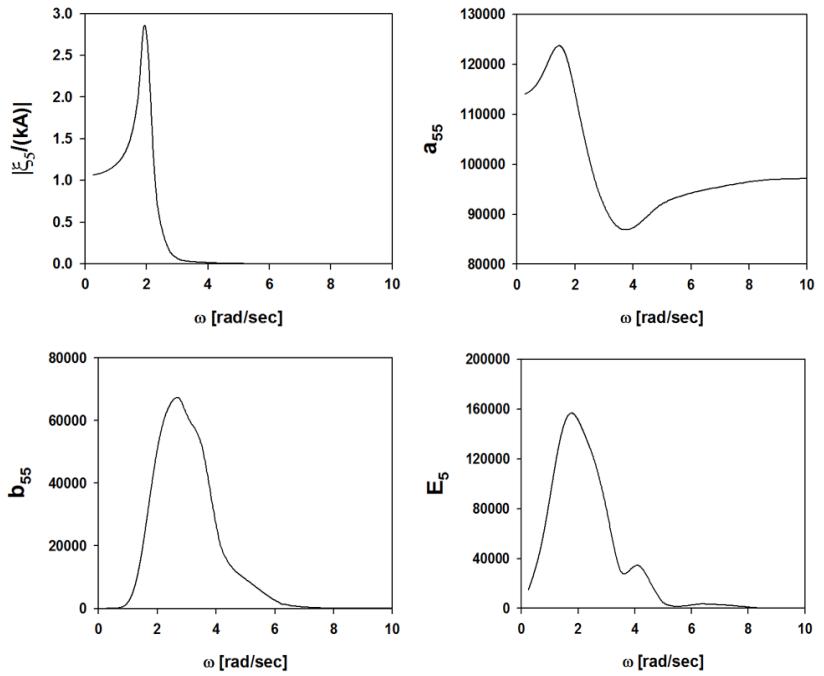

Fig. 5 Pitch RAO, added moment of inertia, radiation damping coefficient and wave exciting moment

수 영역과 고주파수 영역에서 0 에 수렴하며, 피크 값은 각각 $3 \mathrm{rad} / \mathrm{s}$ 와 $2 \mathrm{rad} / \mathrm{s}$ 에서 발생하고 있다.

$$
\begin{aligned}
& -\omega^{2}\left(m_{i j}+a_{i j}\right) \xi_{j}-i \omega b_{i j} \xi_{j}+\left(k_{i j}^{(S)}+k_{i j}^{(M)}\right) \xi_{j}=A E_{i} \quad(i, j=1,2, \ldots, 6) \\
& \omega_{n}=\sqrt{\frac{k_{55}^{(S)}+k_{55}^{(M)}}{m_{55}+a_{55}\left(\omega_{n}\right)}}
\end{aligned}
$$

\section{2 계류시스템 설계}

FMDMS의 계류 방법으로 3점 계류방식을 채택하였으며, 3개 의 외부 기둥 바닥에서 앵커 블록까지 현수선으로 연결하였다 (Fig. 6a, Fig.6b). 각 계류선은 Grade R3 Studlink 타입의 체인으 로 구성되어 있으며 체인의 두께는 $40 \mathrm{~mm}$, 단위 길이당 수중 중 량은 $30.47 \mathrm{~kg}$ 중 $/ \mathrm{m}$, 최소 파단강도(Minimum breaking level, MBL) 는 $1,280 \mathrm{kN}$ 이다(Table 3 ). 계류선의 적절한 길이 선정을 위하여 $55 \mathrm{~m}, 110 \mathrm{~m}, 150 \mathrm{~m}$ 에 대해 OrcaFlex를 이용하여 수치해석을 수행 하였으며, 계류라인의 길이 $110 \mathrm{~m}$ 에 대한 배치형태를 Fig. $6 \mathrm{c}$ 와

Table 3 Specifications of mooring line

\begin{tabular}{lcc}
\hline \hline \multicolumn{1}{c}{ Item } & Unit & Value \\
\hline Chain type & - & Grade R3 Studlink \\
Chain diameter & {$[\mathrm{mm}]$} & 40 \\
Dry weight & {$[\mathrm{kg}$ 중 $/ \mathrm{m}]$} & 35.04 \\
Wet weight & {$[\mathrm{kg}$ 중 $/ \mathrm{m}]$} & 30.47 \\
Minimum breaking load (MBL) & {$[\mathrm{kN}]$} & 1,280 \\
Axial stiffness (EA) & {$[\mathrm{kN}]$} & 161,600 \\
\hline
\end{tabular}




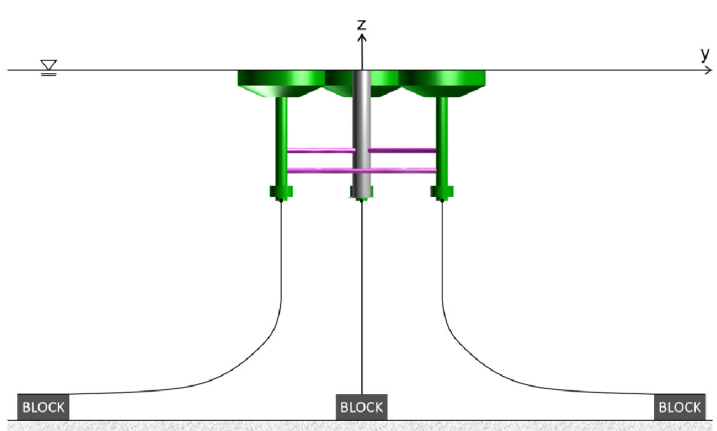

(a) Side view

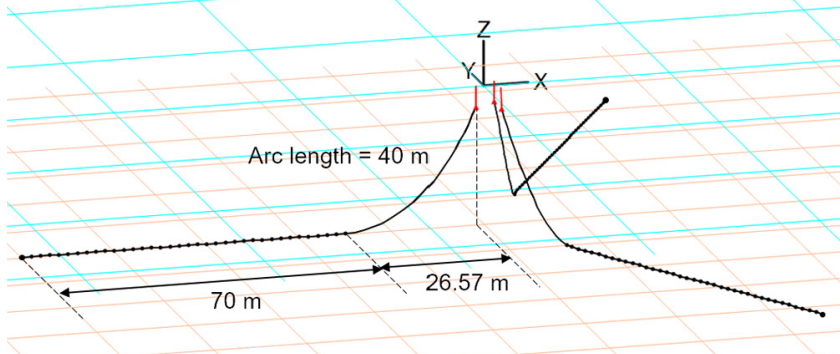

(c) $\operatorname{ML1}(110 \mathrm{~m})$

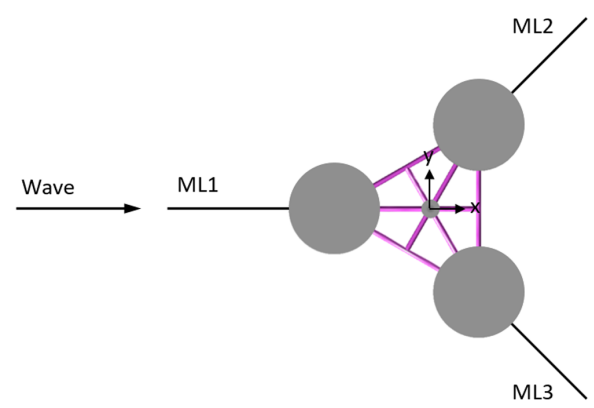

(b) Top view

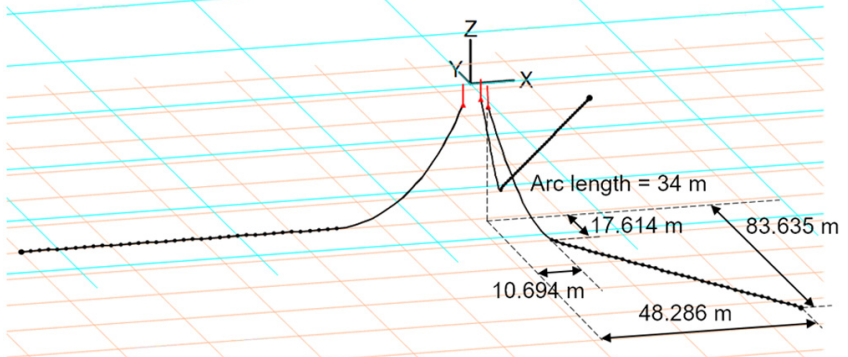

(d) ML3(110m)

Fig. 6 Mooring system of FMDMS

Table 4 Mooring coordinate

\begin{tabular}{|c|c|c|c|c|c|c|c|}
\hline \multirow{2}{*}{ Mooring line length } & \multirow{2}{*}{ Mooring line number } & \multicolumn{3}{|c|}{ Fairlead } & \multicolumn{3}{|c|}{ Anchor } \\
\hline & & $\mathrm{x}[\mathrm{m}]$ & $\mathrm{y}[\mathrm{m}]$ & $\mathrm{z}[\mathrm{m}]$ & $\mathrm{x}[\mathrm{m}]$ & $\mathrm{y}[\mathrm{m}]$ & $\mathrm{z}[\mathrm{m}]$ \\
\hline \multirow{3}{*}{$55 \mathrm{~m}$} & ML1 & -3.175 & 0.0 & -4.52 & -44.784 & 0.0 & -30 \\
\hline & ML2 & 1.585 & 2.9 & -4.52 & 22.371 & 38.903 & -30 \\
\hline & ML3 & 1.585 & -2.9 & -4.52 & 22.371 & -38.903 & -30 \\
\hline \multirow{3}{*}{$110 \mathrm{~m}$} & ML1 & -3.175 & 0.0 & -4.52 & -99.748 & 0.0 & -30 \\
\hline & ML2 & 1.585 & 2.9 & -4.52 & 49.871 & 86.535 & -30 \\
\hline & ML3 & 1.585 & -2.9 & -4.52 & 49.871 & -86.535 & -30 \\
\hline \multirow{3}{*}{$150 \mathrm{~m}$} & ML1 & -3.175 & 0.0 & -4.52 & -142.598 & 0.0 & -30 \\
\hline & ML2 & 1.585 & 2.9 & -4.52 & 71.297 & 123.644 & -30 \\
\hline & ML3 & 1.585 & -2.9 & -4.52 & 71.297 & -123.644 & -30 \\
\hline
\end{tabular}

Fig. 6d에 ML1과 ML3(=ML2)에 대해서 나타내었다. 그리고 계 류라인의 길이 $55 \mathrm{~m}$ 와 $150 \mathrm{~m}$ 에 대한 좌표 값은 Table 4 에 표로 나타내었다.

각 계류선 길이에 따른 복원력 특성을 살펴보고자 오프셋 수 치 시험(Offset numerical test)을 실시하였고, 그 결과를 Fig. 7에 나타내었다. 일반적으로 부이의 수평 이동거리가 증가함에 따라 선형적으로 장력이 증가하다가 일정 거리 이상으로 부이가 이동 하면 계류선이 팽팽하게 당겨져 계류 장력이 비선형적으로 급격 히 증가하는 경향을 보인다. 또한 이동거리와 장력 간에 선형 관계를 보이는 구간은 계류선의 길이가 길어질수록 증가하였다.

안전한 계류시스템 설계를 위해서는 계류 장력의 최댓값이 계 류선의 최소파단강도(MBL)보다 낮아야 하며 설계기준에 적합한 안전계수를 확보하여야 한다. 본 연구에서는 $\mathrm{ABS}(\mathrm{American}$ Bureau of Shipping)의 설계 기준을 따랐다(API, 2005; ABS, 2013). $\mathrm{ABS}$ 설계 기준에 따르면 계류선에 작용하는 장력에 안전계수

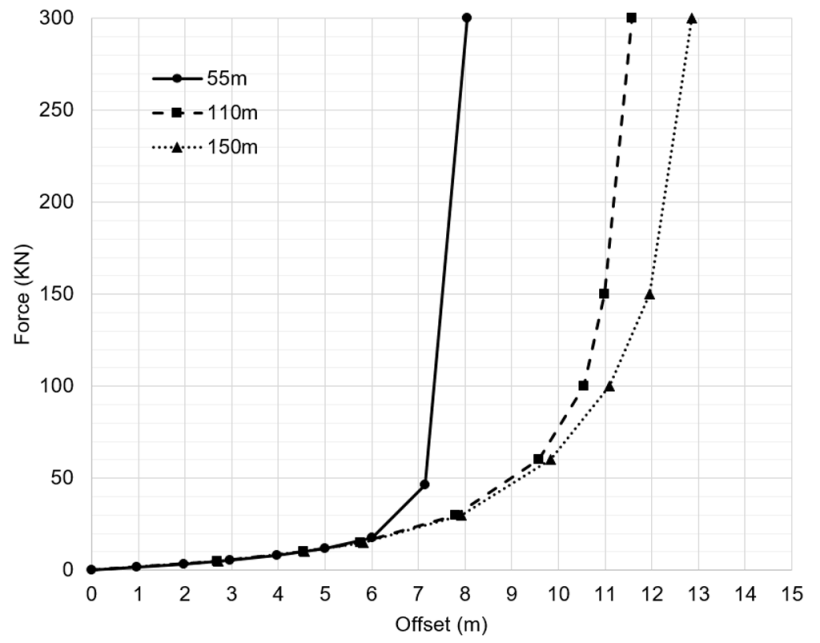

Fig. 7 Results of offset test for each mooring line 


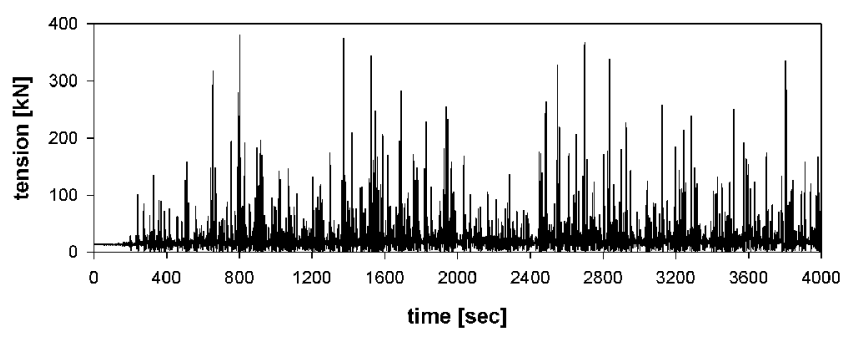

(a)

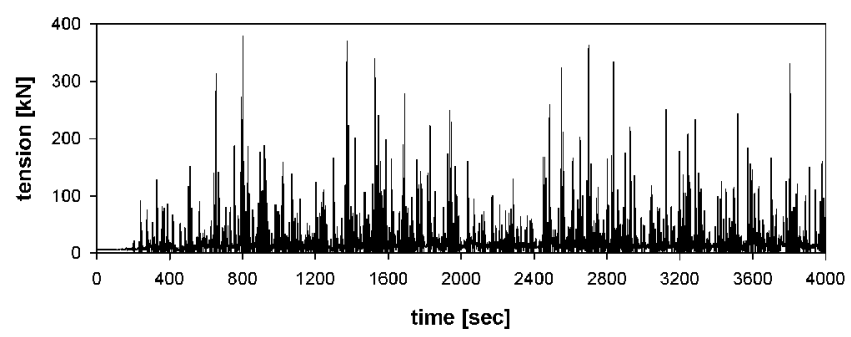

(b)

Fig. 8 Time series of tension for mooring length $110 \mathrm{~m}$ ((a) Tension at the fairlead of ML1, (b) Tension at the anchor point of ML1)

(2.0)를 곱해준 값이 계류선의 $\mathrm{MBL}$ 을 초과하지 않아야 한다. 계 류선의 길이 변화에 따른 계류선에 작용하는 장력을 계산하기 위 하여 계류시스템을 포함한 FMDMS의 시간영역 해석을 진행하였 다. 1 년 재현주기에 해당하는 Table 2 의 환경조건을 적용하였으 며, 보다 안전한 계류시스템 설계를 위하여 조류와 바람의 진행 방향을 파랑의 진행 방향과 동일하게 설정하였다. 이때 가장 큰 장력이 발생하는 계류선은 기상 부이의 전면부에 위치한 ML1이다. Fig. 8은 계류선의 길이가 $110 \mathrm{~m}$ 일 때, ML1 양 끝단(Fairlead, Anchor) 에 작용하는 장력의 시계열 데이터를 보여주고 있다. Table 5는 계류선 길이 변화에 따른 ML1의 양 끝단에 작용하는 최대 장력 $\left(T_{\max }\right)$ 과 파단강도로부터 얻은 확보된 안전계수 그리고 설계기 준 만족 여부를 나타낸다. 계류선에 작용하는 장력의 최댓값은 Rayleigh 3-hour most probable extreme과 3-hour extreme with $1 \%$ risk factor를 적용하여 계산된 값이다. 각 계류선 길이 변화에 따 른 계산 결과를 살펴보면, 계류선의 양 끝단에 작용하는 장력은 $\mathrm{ABS}$ 설계 기준(안전계수:2.0)을 모두 만족하였으며, 계류선의 길 이가 길어질수록 안전계수는 증가하는 것을 확인할 수 있다.

한편, 계류시스템의 한 축을 담당하는 앵커 블록은 콘크리트 블 록으로 설계하였다. 공기 중 콘크리트 블록의 필요 최소 중량은 $W=\frac{T_{\max }\left(\cos \theta_{0}+\mu \sin \theta_{0}\right)}{\mu\left(1-\rho g / \sigma_{A}\right)}$ 이다. 여기서 $T_{\max }$ 는 앵커점에서의 최
대 장력, $\theta_{0}$ 는 계류선과 해저면 사이의 각도이다. $\mu$ 는 해저면 마찰 계수로 0.7 을 적용하였으며, $\rho g$ 는 단위 체적 당 해수의 중량 $(1025 \mathrm{~kg}$ 중 $\left./ \mathrm{m}^{3}\right), \sigma_{A}$ 는 단위 체적 당 콘크리트의 중량 $\left(2400 \mathrm{~kg}\right.$ 중 $\left./ \mathrm{m}^{3}\right)$ 이다. 계 류선의 길이 $55 \mathrm{~m}, 110 \mathrm{~m}, 150 \mathrm{~m}$ 대하여 Table 5 에 나타난 앵커점에서 의 최대장력을 적용하여 구한 콘크리트 블록의 최소 중량은 각각 77.11ton, 51.22ton, 44.44ton이다. 앵커중량은 계류선의 길이가 짧 을수록 증가하는 것을 확인하였다.

이상의 결과로부터, 계류선의 길이가 길어질수록 안전성 측면 에서 유리하며 앵커 중량은 계류선의 길이가 증가할수록 감소 하는 것을 확인하였다. 계류선의 길이를 너무 길게 또는 너무 짧게 설계하면 그에 따른 계류선과 앵커블록 제작비용이 증가 할 뿐만 아니라 선박 운항의 지장과 이송·설치에 따른 어려움이 발생한다. 본 연구에서는 제작 및 안전성 측면을 종합적으로 고 려하여 계류선의 길이를 $110 \mathrm{~m}$ 로 선정하였다.

\section{4. 모형실험}

모형실험은 수치해석 결과의 검증 및 해석적으로 고려할 수 없는 비선형 특성들을 파악하기 위해 수행되는 매우 중요한 설 계 단계중 하나이다. 본 연구에서는 축척비 $1 / 10$ 을 갖는 실험 모형을 제작하여 중소조선연구원의 사각형 조파수조에서 Froude 축척법에 따라 파랑중 운동실험을 실시하였다. Fig. 9는 제작 모형의 3 차원 $\mathrm{CAD}$ 도면과 제작 후 모형 사진을 보여주고 있다. Table 6에 모형의 제원을 수록하였다.

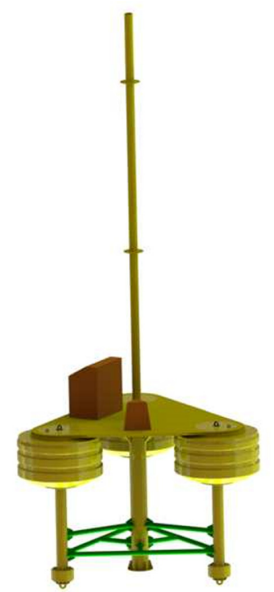

(a)

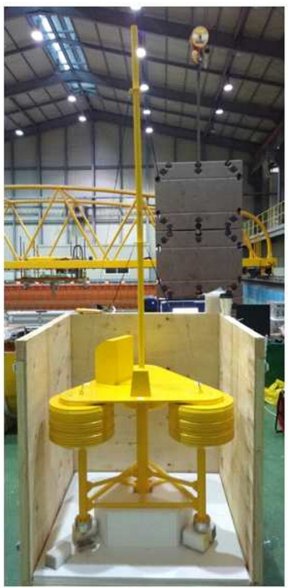

(b)
Fig. 9 (a) 3D CAD drawing, (b) Experimental model

Table 5 Results of mooring system

\begin{tabular}{|c|c|c|c|c|c|}
\hline \multirow{2}{*}{ Mooring line length [m] } & \multirow{2}{*}{ ML1 } & \multicolumn{3}{|c|}{ Tension } & \multirow{2}{*}{$\begin{array}{c}\text { Anchor block weight in } \\
\text { air [ton] }\end{array}$} \\
\hline & & $T_{\max }[\mathrm{kN}]$ & Safety factor & ABS compliance $(\mathrm{Y} / \mathrm{N})$ & \\
\hline \multirow{2}{*}{55} & Fairlead & 315 & 4.06 & $\mathrm{Y}$ & \multirow{2}{*}{77.11} \\
\hline & Anchor & 252 & 5.06 & $\mathrm{Y}$ & \\
\hline \multirow{2}{*}{110} & Fairlead & 234 & 5.46 & $\mathrm{Y}$ & \multirow{2}{*}{51.22} \\
\hline & Anchor & 192 & 6.66 & Y & \\
\hline \multirow{2}{*}{150} & Fairlead & 224 & 5.70 & $\mathrm{Y}$ & \multirow{2}{*}{44.44} \\
\hline & Anchor & 170 & 7.49 & $\mathrm{Y}$ & \\
\hline
\end{tabular}


Table 6 Specifications of experimental model and mooring line

\begin{tabular}{lcc}
\hline \hline \multicolumn{1}{c}{ Item } & Unit & Value \\
\hline Mass & {$[\mathrm{kg}]$} & 15.92 \\
Draft & {$[\mathrm{m}]$} & 0.4382 \\
CoG from SWL $\left(z_{G}\right)$ & {$[\mathrm{m}]$} & -0.099 \\
Pitch moment of inertia (about CoG) & {$\left[\mathrm{kg} \cdot \mathrm{m}^{2}\right]$} & 1.6832 \\
GM & {$[\mathrm{m}]$} & 0.6309 \\
Depth & {$[\mathrm{m}]$} & 2 \\
Mooring length & {$[\mathrm{m}]$} & 11 \\
Mooring weight in water per unit length & {$[\mathrm{kg}$ 중 $/ \mathrm{m}]$} & 0.3 \\
Heave natural frequency & {$[\mathrm{rad} / \mathrm{s}]$} & 8.267 \\
Pitch natural frequency & {$[\mathrm{rad} / \mathrm{s}]$} & 5.764 \\
\hline
\end{tabular}

중소조선연구원에서 보유하고 있는 조파수조의 조파기는 피 스톤 타입이며 조파기 반대편에는 반사파를 줄여주기 위한 비 치형 소파장치가 설치되어 있다. 실험모형은 조파기로부터 약 $10.8 \mathrm{~m}$ 에 위치하며, 3점 계류방식으로 계류선의 양 끝단은 모형 과 수조 바닥면에 고정되었다. 앵커에서 모형 중심까지의 직선 거리는 $9.96 \mathrm{~m}$ 이며, 계류선은 체인을 사용하였다. Fig. 10(a)와 Fig. 10(b)는 각각 사각형 수조에 설치된 앵커 배치도와 실험 모 형을 보여주고 있다.

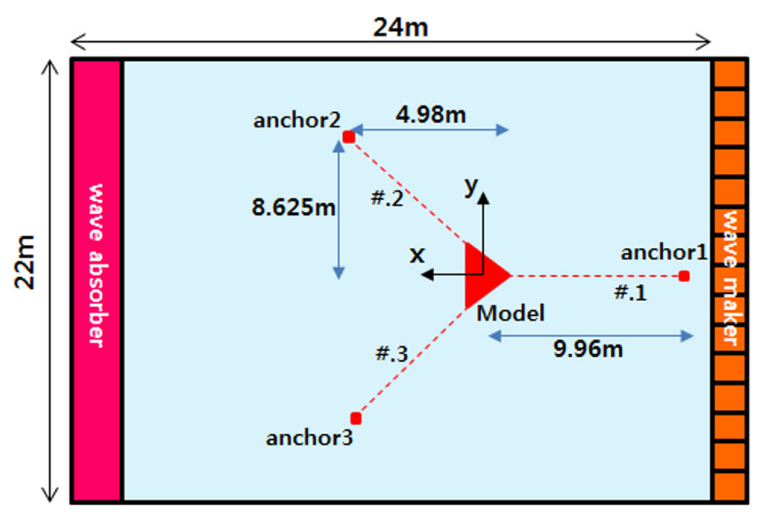

(a)

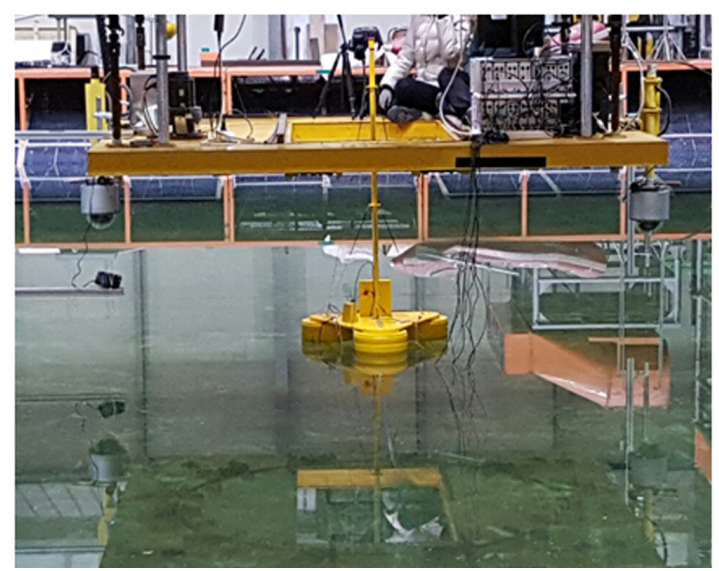

(b)

Fig. 10 (a) Configuration of model and mooring lines, (b) Experimental model in wave tank

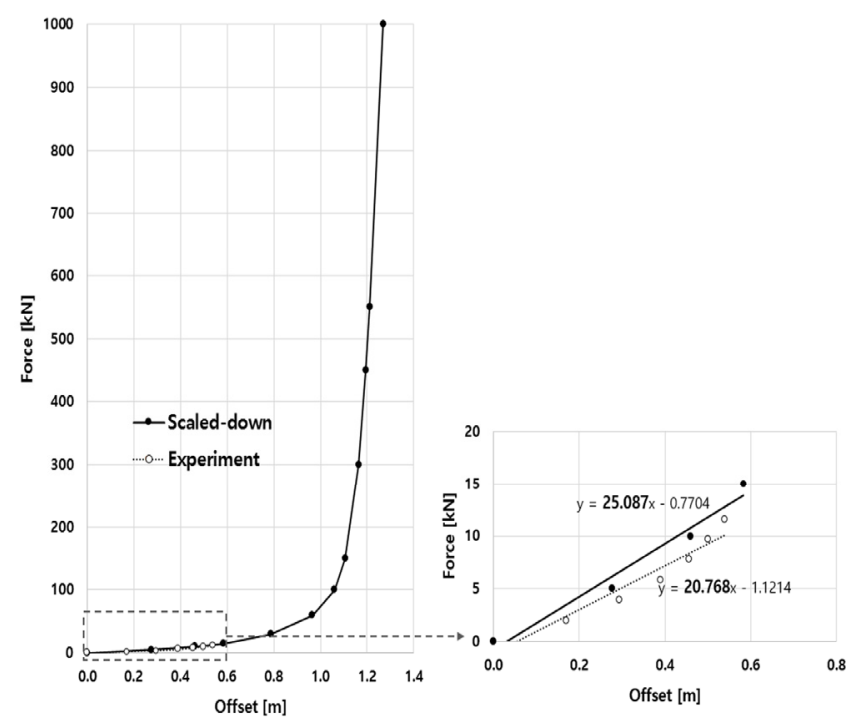

Fig. 11 Mooring restoring force coefficient obtained from offset test

모형과 실선의 계류선 강성계수를 동일하게 맞춰주기 위하여 오프셋 시험을 실시하였고, 파랑중 운동응답은 규칙파와 불규 칙파 조건에서 살펴보았다. 오프셋 시험에서는 모형의 무게중 심에 가는 와이어를 연결하여 일정 무게의 추를 순차적으로 증 가시켜가며 $x$ 축 방향으로 이동하는 모형의 이동 변위를 측정하 였다. 오프셋 시험 결과는 수치해석 결과와 비교하였다. Fig. 11 에서 보듯이 선형 구간에서 비교적 잘 일치하는 결과를 얻었다. 수치해석 결과의 계류 강성계수는 $25.087 \mathrm{~N} / \mathrm{m}$ 이며, 실험 결과는 $20.768 \mathrm{~N} / \mathrm{m}$ 이다.

Table 7과 Table 8은 규칙파와 불규칙파에 대한 입사파 조건 들을 나타내었다. FMDMS의 공진 특성을 살펴보기 위하여 규 칙파 실험에서는 모형의 수직과 종 운동의 고유주파수를 포함 한 범위 내에서 총 13 개의 주파수(Case 01 13)를 선정하였다. 불규칙파 조건은 Fig. 3 의 제주도 월정 해역의 파랑조건을 $1 / 10$ 으로 축소하여 총 5 케이스(Case 101 105)를 선택하였다. 불규 칙파 생성을 위하여 JONSWAP 스펙트럼을 사용하였으며, Case 101 과 Case 102 의 경우, 중소조선연구원 조파기의 과부하를 고 려하여 기하학적 상사성을 만족하는 유의파고 $(0.167 \mathrm{~m}, 0.102 \mathrm{~m})$ 보다 낮은 유의파고 $0.1 \mathrm{~m}$ 로 실험을 실시하였다. 그리고 모형실 험에서는 조류 및 바람의 영향은 고려하지 않았다. 한편, 다수 의 주파수가 공존하는 불규칙파는 피크주파수 근처에 대부분의 에너지가 분포하며, 공진 회피를 위하여 FMDMS의 수직, 종 운 동 고유주파수를 각 케이스의 피크주파수보다 고주파수 영역에 위치하도록 설정하였다.

규칙파 실험은 모든 케이스에 대하여 60 초 동안 파를 생성하 여 실험을 진행하였으며, 모형의 수직운동과 종 운동 변위를 반 사파의 영향이 미치기 전까지 계측하였다. Fig. 12는 수직 운동 $\mathrm{RAO}\left(\left|\xi_{3} / A\right|\right)$ 에 대한 결과로 실선은 WAMIT 상용코드를 이용한 해석 결과를 나타내며, 동그라미는 실험결과이다. 두 결과는 정 성적으로 잘 일치하는 경향을 보이고 있다. 공진주파수에서 수 직 운동의 피크 값은 1.2 를 보이며, 그 외의 주파수에서는 모두 1 미만의 값을 보여주고 있다. 이러한 결과는 FMDMS의 수직 운동이 매우 작게 나타났음을 의미하며, 수면에 위치한 직경이 
Table 7 Regular wave conditions

\begin{tabular}{cccccccccc}
\hline \hline & Case & & 01 & 02 & 03 & 04 & 05 & 06 & 07 \\
\hline$\omega$ & & {$[\mathrm{rad} / \mathrm{s}]$} & 8.98 & 8.38 & 7.85 & 7.39 & 6.98 & 6.61 & 6.28 \\
$H$ & {$[\mathrm{~m}]$} & 0.023 & 0.026 & 0.030 & 0.023 & 0.025 & 0.028 & 0.031 \\
$H / \lambda$ & - & 0.03 & 0.03 & 0.03 & 0.02 & 0.02 & 0.02 & 0.02 \\
\hline & Case & & 08 & 09 & 10 & 11 & 12 & 4.49 \\
$H$ & & {$[\mathrm{rad} / \mathrm{s}]$} & 5.98 & 5.71 & 5.46 & 5.24 & 4.83 & 0.061 \\
$H / \lambda$ & {$[\mathrm{m}]$} & 0.034 & 0.038 & 0.041 & 0.045 & 0.053 & 0.02
\end{tabular}

Table 8 Irregular wave conditions (JONSWAP spectrum)

\begin{tabular}{|c|c|c|c|c|c|c|}
\hline \multicolumn{2}{|c|}{ Case } & 101 & 102 & 103 & 104 & 105 \\
\hline$H_{s}$ & {$[\mathrm{~m}]$} & 0.1 & 0.1 & 0.102 & 0.107 & 0.055 \\
\hline$\omega_{p}$ & {$[\mathrm{rad} / \mathrm{s}]$} & 2.61 & 3.24 & 2.24 & 3.07 & 3.29 \\
\hline$\gamma$ & - & & & 1.0 & & \\
\hline
\end{tabular}

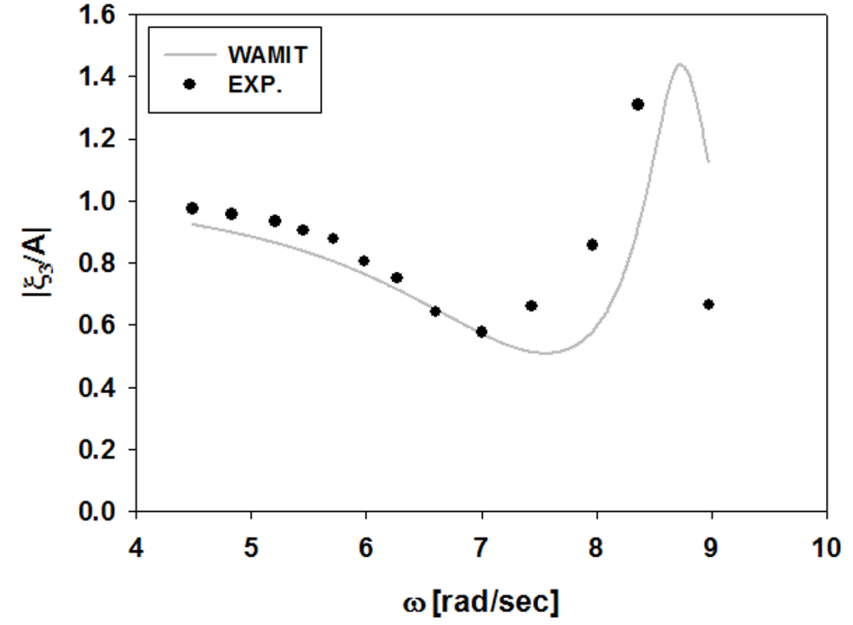

Fig. 12 Comparison of heave RAO between the numerical and experimental results

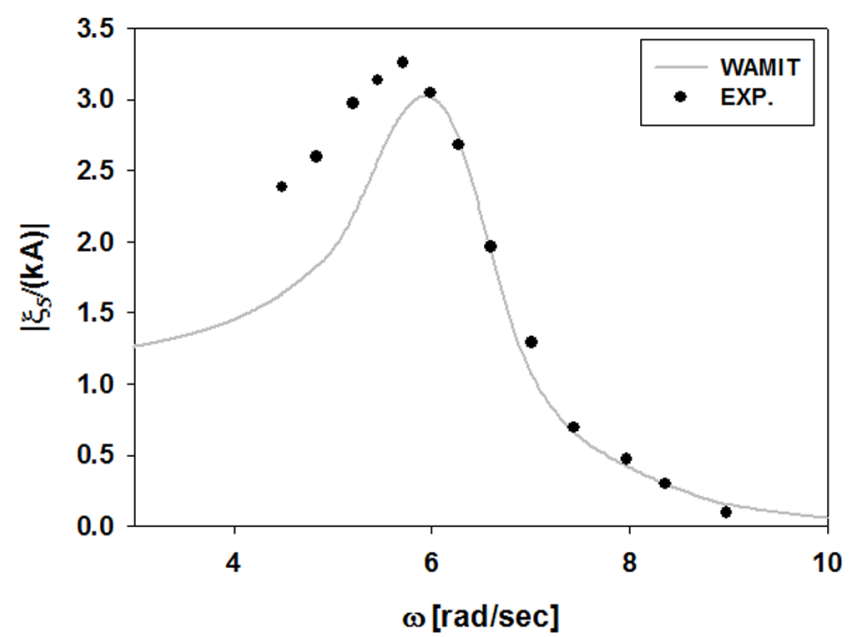

Fig. 13 Comparison of pitch RAO between the numerical and experimental results
큰 3 개의 폰툰으로 인해 방사 및 점성 감쇠력이 크게 증가하였 기 때문으로 사료된다.

Fig. 13은 종 운동 $\left(\left|\xi_{5} /(k A)\right|\right)$ 에 대한 수치 계산결과와 실험결 과를 보여주고 있다. 두 결과는 정성적으로 서로 잘 일치하고 있음을 확인할 수 있다. FMDMS의 종 운동은 수직운동에 비해 공진주파수 대역이 넓으며, 공진주파수를 기준으로 고주파수 영역으로 이동할수록 종 운동은 급격히 줄어드는 반면, 저주파 수 영역에서는 상대적으로 완만하게 감소하는 특징을 가지고 있다. RAO 곡선의 피크 값을 살펴보면, 수직 운동에 비해 종 운동은 상대적으로 크게 발생하고 있음을 알 수 있다.

불규칙파 실험 결과는 스펙트럼 분석과 Zero-crossing 방법을 적용한 파의 유의파고 및 모형의 유의 운동고 $\left(=\left(2 \xi_{5}\right)_{1 / 3}\right)$ 를 산출 하여 나타내었다. 파랑 스펙트럼과 FMDMS의 수직 및 종 운동 스펙트럼은 계측된 시계열 데이터를 FFT(Fast fourier transform) 을 사용하여 구하였다. 실선은 파랑스펙트럼, 짧은 파선은 수직 운동스펙트럼, 긴 파선은 종 운동스펙트럼을 나타낸다(Fig. 14). 수직운동의 경우, 공진주파수 영역에서는 입사파의 에너지가 크지 않기 때문에 FMDMS의 수직운동이 크게 발생하지 않았다. 따라서 수직운동의 에너지 분포는 완만한 곡선을 갖는다. 반면 에 종 운동의 경우, 공진주파수 부근에서는 비록 작지만 입사파 의 에너지가 존재하므로 공진 현상이 발생하여 모든 케이스에 대하여 종 운동이 크게 발생하는 것을 볼 수 있다. 특히, Case 101 과 Case 103 에서는 종 운동이 공진주파수 외에 장주기 영역 에 속하는 입사파의 피크 주파수에서 또 다른 피크 값이 나타 났다. 이는 설계된 FMDMS가 수면 근처에 위치한 3 개의 큰 폰 툰으로 인해 장주기 입사파의 경사면을 따라 움직이기 때문이 다. 입사파의 피크주파수에서 종 운동변위를 줄이기 위해서는 점성 감쇠력을 증가시킬 수 있도록 감쇠판 부착하는 방법 등을 고려해 볼 필요가 있다. Fig. 15는 Case 102에 대한 모형실험의 시계열 데이터를 보여주고 있다. 스펙트럼 분석에서 예상할 수 있듯이, 전반적으로 수직운동은 작게 나타나며, 종 운동은 다소 크게 발생하고 있음을 볼 수 있다. 각 불규칙파 실험 케이스에 대한 자세한 통계적 대폿값을 Table 9에 정리하였다. 


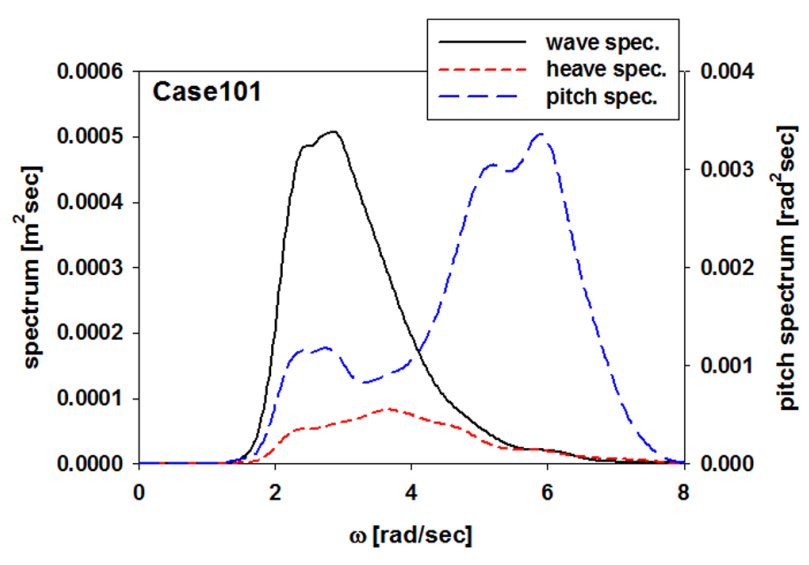

(a) Case 101

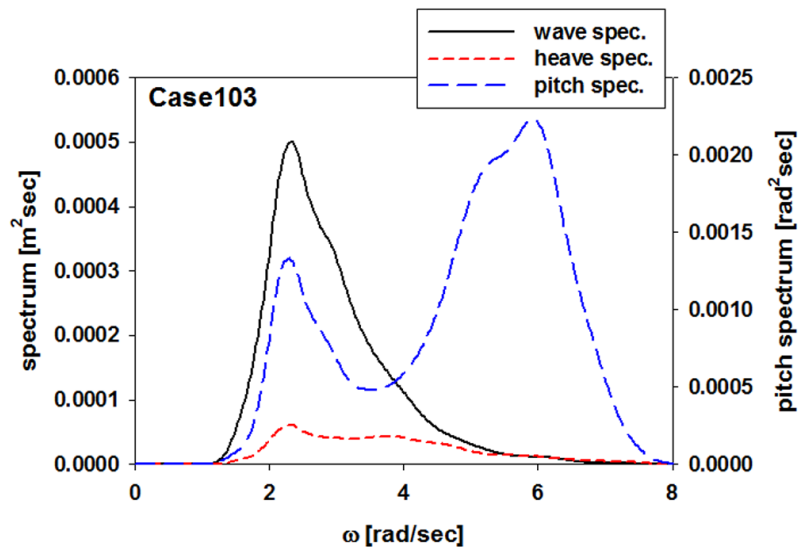

(c) Case 103

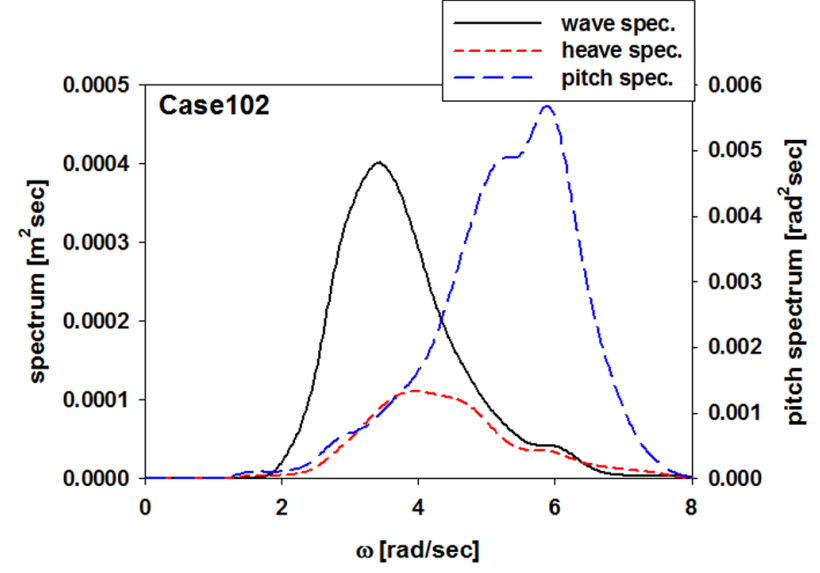

(b) Case 102

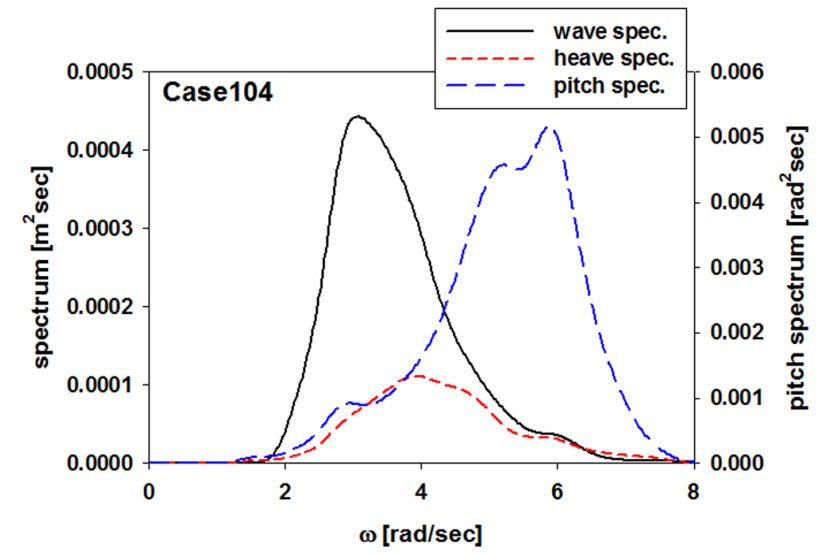

(d) Case 104

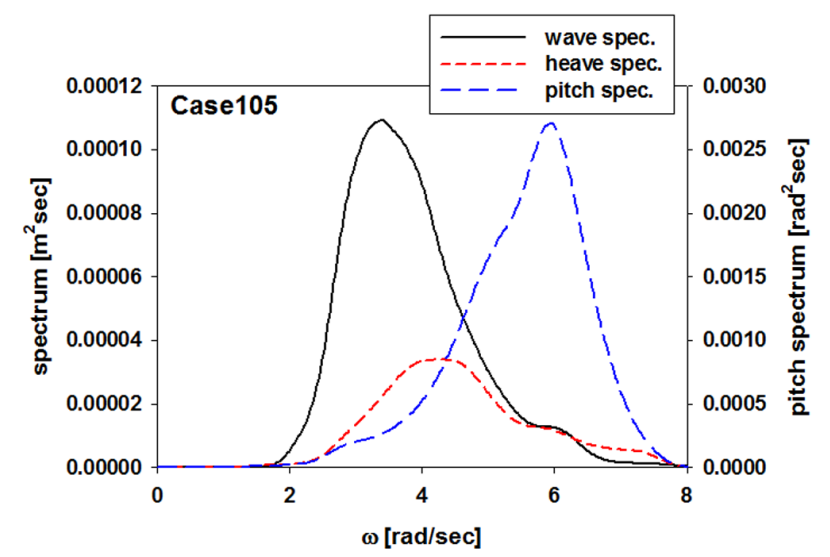

(e) Case 105

Fig. 14 Wave and motion spectrum for irregular wave conditions

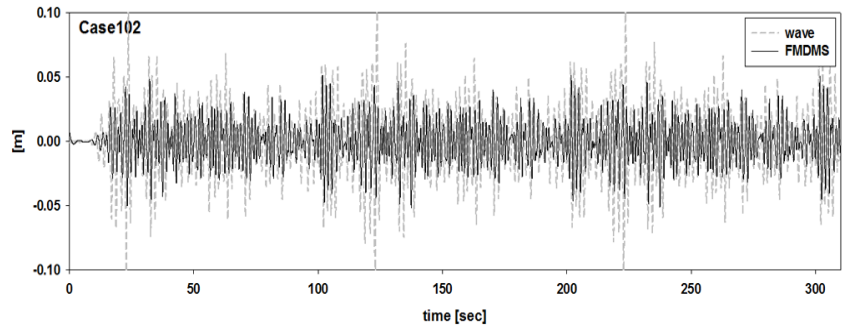

(a)

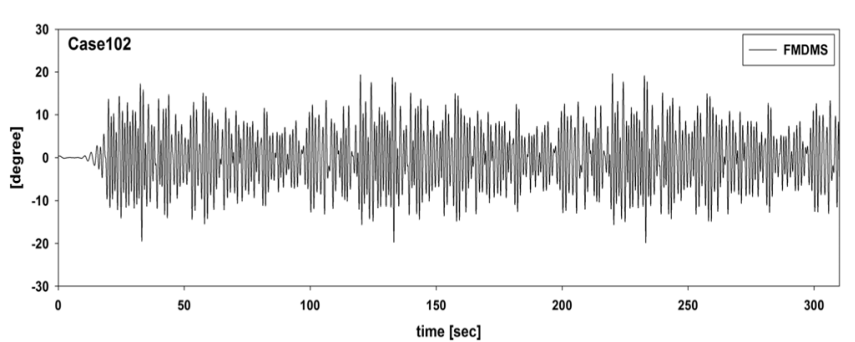

(b)

Fig. 15 Time series of wave and motion of FMDMS for case 102 (a: wave and heave, b: pitch) 
Table 9 Experimental results for irregular wave

\begin{tabular}{cccc}
\hline \hline \multirow{2}{*}{ Case } & $H_{s}$ & $\left(2 \xi_{3}\right)_{1 / 3}$ & $\left(2 \xi_{5}\right)_{1 / 3}$ \\
\cline { 2 - 4 } & {$[\mathrm{m}]$} & {$[\mathrm{m}]$} & {$[\mathrm{deg}]$.} \\
\hline 101 & 0.1197 & 0.0568 & 20.5875 \\
102 & 0.1107 & 0.0637 & 24.2575 \\
103 & 0.1047 & 0.0477 & 17.0323 \\
104 & 0.1152 & 0.0638 & 23.5961 \\
105 & 0.0574 & 0.0356 & 16.0076 \\
\hline
\end{tabular}

\section{5. 결 론}

LiDAR 탑재된 기상 부이를 개발하기 위하여 일반적인 부유 식 해상 구조물의 설계 절차에 따라 설계를 진행하였다. 본 연 구에서 제시된 부유식 해상 기상 부이(FMDMS)는 일반적으로 사용되는 원반형이나 스파형 부이가 아닌 3 개의 폰툰을 삼각형 으로 배열된 새로운 형태이며, 갑판 위에 높은 고도의 바람 자 료를 취득하기 위해 LiDAR 장비가 탑재된다. LiDAR 장비의 정 확도는 $\mathrm{FMDMS}$ 의 종 운동에 큰 영향을 받으므로 종 운동 저감 에 초점을 맞춰 수치해석과 모형실험 결과를 살펴보았다. FMDMS의 부가질량, 방사 감쇠계수 그리고 파기진력을 계산하 기 위하여 상용 프로그램인 WAMIT을 사용하였다. FMDMS의 계류시스템 설계는 1 년 재현주기에 해당하는 극한환경조건 $\left(H_{s}=5.74 \mathrm{~m}, T_{p}=10.81 \mathrm{~s}\right)$ 에서 수행되었고, $\mathrm{ABS}$ 설계 기준(안전 계수 $=2.0$ )에 따라 안전성을 평가하였다. 부유체-계류시스템 상 호작용 해석 프로그램인 OrcaFlex을 이용한 시간영역 해석을 수 행한 결과, 앵커 블록의 중량과 안전성을 고려하여 계류선의 길 이를 $110 \mathrm{~m}$ 로 결정하였다.

FMDMS의 운동 실험은 $1 / 10$ 의 축척비를 갖는 모형을 제작하여 중소조선연구원 조파수조에서 실시하였다. 이때 오프셋 시험을 통하여 모형과 실물의 계류 로프의 강성계수를 같게 맞추었다. 규 칙파, 불규칙파 실험을 통하여 운동특성을 분석한 결과, FMDMS 모형은 공진 회피 설계를 반영했음에도 불구하고 종 운동이 크게 발생하였으며, 이는 수면에 위치한 직경이 큰 폰툰으로 FMDMS 가 파의 경사면을 따라 운동하였기 때문이다. FMDMS의 종 운동 을 줄이기 위해서는 3 개의 외부 기둥 바닥면에 감쇠판을 부착하 는 방법과 폰툰의 크기를 줄이는 방법이 적절할 것으로 사료된다. 반면에 수직운동은 대형 폰툰에 의한 감쇠력(점성 감쇠력+파랑 감쇠력)의 증가로 크게 나타나지 않았다.

\section{후기}

본 연구는 한국에너지기술연구원의 KETEP 지원사업으로 수 행한 결과입니다.

\section{References}

American Bureau of Shipping(ABS), 2013. Rules for Building and Classing Floating Production Installations. American Bureau of Shipping.

Americal Petroleum Institute(API), 2005. Recommended Practice for Design and Analysis of Stationkeeping Systems for Floating Structures: API Recommended Practice 2SK. $3^{\text {rd }}$ edition, American Petroleum Institute.

Cho, K.N., Yi, W.S., 1997. A Study on the Conceptual Design of Oceanographic Buoy Systems. Journal of Ocean Engineering and Technology, 11(4), 205-212.

Jaynes, D.W., McGowan, J.G., Rogers, A.L., Manwell, J.F., 2007. Validation of Doppler lidar for wind resource assessment applications. In AWEA Windpower2007 Conference.

Jaynes, D.M., Hassan, G.G., 2011. Investigating the efficacy of floating lidar motion compensation algorithms for offshore wind resource assessment applications. In European Wind Energy Conference.

Kim, S.J., 2003. A study regarding investigation and analysis of the wind characteristics and a analysis of the economical efficiency for wind turbine system. Proceeding of The Korean Institute of Power Electronics, 7(1), 371-374.

Kim, K.H., Lee, K., Sohn, J.M., Park, S., Choi, J.S., Hong, K., 2015. Conceptual Design of Large Semi-submersible Platform for Wave-Offshore Wind Hybrid Power Generaion. Journal of the Korean Society for Marine Environment \& Energy, 13(3), 1-10.

Lee, D.K., Oh, J,H., Suh, Y.S., 1999. The Development of MiniWeather Buoy. Journal of the Korean Society of Oceanogrphy, 4(2), 155-159.

Lee, Y.N., Shin, H.Y., 2012. A study of revaluation for wind power systems in Saemangeum demonstration site. Proceeding of The Korean Solar Energy Society, 370-375.

Mathisen, J.P., 2013. Measurement of wind profile with a buoy mounted lidar. Energy Procedia, (00), 12.

Moon, C.j., Chang, Y.H., Jeong, M.S., Joo, H.J., Kwag, D.J., Jeong, G.S., 2013. Design and Construction of Offshore Meteorological Tower. Proceeding of The Korean Society for Marine Environment \& Energy, 219-223. 